\title{
TINJAUAN BUDAYA PIDATO PRESIDEN JOKO WIDODO PASCA VAKSINASI PERTAMA DI INDOESIA
}

\author{
Emma Ratna Sari Moedy \\ Fakultas Ilmu Sosial dan Ilmu Politik Universitas Mahendradatta \\ emmamoedy@gmail.com
}

\begin{abstract}
Abstrak - Pidato yang singkat saat Presiden Jokowi pada tanggal 13 Januari 2021 mendapatkan vaksinasi pertama ini melahirkan wacana besar mengenai keterlibatan semua pihak dalam satu masalah, tidak memandang SARA dan golongan. Interaksi yang terjadi menyentuh ranah global karena diberitakan melalui jaringan media sampai ke ranah kelompok-kelompok kecil melalui aplikasi-aplikasi media sosial. Interaksi melalui media mengena kepada golongan tua, muda sampai milenial untuk membuktikan bahwa vaksinasi ini hanya salah satu cara untuk memastikan setiap orang mendapatkan alternatif solusi kesehatan di masa pandemi selain kebiasaan yang diterapkan dalam protokol kesehatan yaitu cuci tangan, memakai masker dan jaga jarak. Indonesia sebagai negara berpenduduk muslim terbesar harus memastikan bahwa vaksin yang beredar telah tersertifikasi halal. Kesiapan mental penting untuk dipahami dan dilaksanakan melalui mitigasi atau pencegahan secara terus menerus dan berkesinambungan. Masyarakat harus memahami dan belajar dari penanganan bencana di negara lain.
\end{abstract}

Kata kunci: pandemic; Covid-19; man sana incorpore sano; mitigasi; pidato

\begin{abstract}
This short speech when President Jokowi received the first vaccination gave birth to a large discourse regarding the involvement of all parties in one problem, regardless of racial and group interests. The interactions that occur touch the global realm because they are reported through media networks to the realm of small groups through social media applications. Interaction through the media reaches the old, young and millennial groups to prove that vaccination is only one way to ensure that everyone gets alternative health solutions during a pandemic in addition to the habits implemented in health protocols, namely washing hands, wearing masks and keeping your distance. Indonesia as the country with the largest Muslim population must ensure that the vaccines in circulation are halalcertified. Mental readiness is important to understand and implement through continuous and continuous mitigation or prevention. The community must understand and learn from disaster management in other countries.
\end{abstract}

Keywords: pandemic; Covid-19; man sana incorpore sano; mitigation; speech

\section{Latar Belakang Masalah}

Man sana in corpore sano yang berarti dalam tubuh yang sehat terdapat jiwa yang sehat pula. Bahkan kesehatan menjadi kebutuhan mendasar seseorang sehingga mampu beraktivitas secara normal. Di Indonesia sendiri isu pandemi corona telah santer diberitakan 
sejak kasusnya membuat warga Wuhan, China, harus di-lock down. Indonesia sendiri mulai mengatur strategi mengatasi ini. Terhitung Maret 2020, telah diupayakan penutupan daerahdaerah tergantung status kesiagaannya (zona merah, hijau, kuning).

Salah satu cara pencegahan terhadap serangan virus jahat adalah melalui vaksinasi. Indonesia lewat fasilitas seperti Puskesmas telah terbiasa melakukan vaksinasi massal bagi balita atau vaksinasi mandiri di rumah sakitrumah sakit di seluruh Indonesia. Untuk itu setiap balita memiliki Kartu Menuju Sehat (KMS) yang berisi skala kesehatan terhadap ukuran kepala, berat badan dan tinggi badan. Dari sana didapatkan kualitas dan kuantitas yang terukur di setiap masa pertumbuhan secara gratis.

Isu vaksinasi menjadi penting di tengah pasang surutnya kondisi fisik dan mental bangsa Indonesia. Orangpertama disuntikkan vaksin pencegah Covid-19 adalah Presiden Joko Widodo. Banyak ujian dari pemerintahan Jokowi di era pandemi. Mulai dari isu pergantian cabinet yang ternyata benar dilaksanakan dan dilantik Desember 2020. Menteri Sosial yang disangkakan korupsi bantuan sosial digantikan Walikota Surabaya, Tri Risma Harini. Di awal tahun 2021 terdapat kecelakaan penerbangan Sriwijaya Air dari Jakarta tujuan ke Pontianakyang jatuh diKepulauan seribu, banjir di Kalimantan,dan juga gempa. Badan Meteorologi dan Klimatologi (BMKG) telah mengumumkan akan terjadi angin dan gelombang pasang di Selatan Indonesia yakni di Samudera Hindia.
Salah satu solusi dari pandemi ini, untuk pertama kalinya vaksin disuntikkan kepada Presiden Joko Widodo. Peristiwa ini menjadi perhatian global baik di media mainstream maupun media sosial yang secara langsung disiarkan secara publik. Berikut adalah petikan pidato resmi pertama Presiden Joko Widodo pasca mendapapatkan vaksinasi yang dilansir dari Detik.com:

Bapak, Ibu, dan Saudara-saudara semua sebangsa dan setanah air, baru saja saya tadi bersama-sama dengan perwakilan dari bidang kesehatan, perwakilan agama, perwakilan pedagang pasar, perwakilan pengusaha, perwakilan buruh, perwakilan guru dan dari perwakilan tenaga kesehatan telah melakukan vaksinasi.

Dari kesehatan terima kasih telah bersama-sama dengan saya tadi divaksin Bapak Ketua IDI, Bapak Daeng $M$ Faqih, dan juga dari perwakilan agama saya ingin ucapkan terima kasih kepada Bapak Kiai Ishomuddin, kemudian dari sekjen MUI Bapak Amiesyah Tambunan beliau juga tokoh Muhammadiyah dan Bapak Kiai Ishomuddin dari Nahdlatul Ulama dan juga perwakilan guru hadir langsung Ketua PGRI, Prof Unifah Rosyidi, kemudian dari Ketua PPNI Pak Arif dan Sekjen Ikatan Bidan Bu Ade Zubaedah, serta dari perwakilan buruh Ibu Agustini Setiorini dan juga perwakilan dari PGI, KWI, PHDI, Permabudhi, dari Matagin, juga ada Ibu Narti pedagang sayur inpres gading Jakarta Utara, hadir juga serta perawat Ibu Nur dari Dinkes DKI dan dari lain-lainnya. 
Setelah kita melakukan vaksinasi perdana ini nanti akan terus dilanjutkan vaksinasi di seluruh provinsi, kabupaten dan kota di seluruh tanah air. Vaksinasi ini dilakukan setelah kita mendapat izin penggunaan darurat emergency use authorization dari BPOM dan juga telah keluarnya fatwa halal dari MUI, kami mengucapkan terima kasih yang sebesar-besarnya

Vaksinasi COVID-19 ini penting untuk kita lakukan untuk memutus rantai penularan virus Corona ini dan memberikan perlindungan kesehatan kepada kita, dan keselamatan, keamanan kepada kita semua masyarakat Indonesia dan membantu percepatan proses pemulihan ekonomi. Terakhir meskipun telah dilaksanakan vaksinasi, saya ingin mengingatkan kembali tentang pentingnya disiplin terhadap protokol kesehatan ini tetap kita lakukan, memakai masker, mencuci tangan menjaga jarak dan menghindari kerumunan. Saya rasa itu yang bisa saya sampaikan pada kesempatan yang baik ini, sekali lagi saya juga ingin mengucapkan terima kasih kepada Prof dokter Abdul Muthalib yang tadi menyuntikkan vaksin kepada saya, terima kasih.

\section{Analisa}

Cuplikan pidato di atas menggambarkan pemimpin mendapatkan ruang khusus di hati masyarakat Indonesia. Dari statusnya pemimpin lahir karena keturunan sehingga menjadi pemimpin adalah kodrat duniawi dan tidak terelakkan. Semacam Pangeran William dari Inggris
Raya yang digadang-gadang akan menjadi pewaris tahta di masa depan. Ada pula status pemimpin terjadi karena pencapaian, dalam hal ini seorang pemimpin layak "naik tahta" karena memiliki kemampuan dan diharapkan memiliki itikad baik dan integritas yang tinggi. Terakhir, status menjadi pemimpin, lahir karena diberikan tanda jasa atau tanda kehormatan oleh yang berwenang seperti pemberian Kalpataru dari Presiden kepada pemimpin masyarakat yang telah melakukan aksi sosial kepada lingkungannya.

Apapun jenisnya, pemimpin diharuskan mrmiliki soft skill dan hard skill. Soft skill mencakup: 1. Kemampuan untuk berkomunikasi, lentur dalam birokrasi, hormat dan taat pada aturan, memiliki komitmen bagi lingkungan sekitar di mana ditugaskan sehingga menghasilkan komunikasi yang jelas ke mana arahnya, serta konsisten bergerak, dan berupaya melalui saluran komunikasi yang sesuai dan tepat sasaran; 2. mampu menjadi soko guru bagi yang dipimpinnya, mampu memberikan berita yang sahih, memiliki kecepatan dalam pengambilan keputusan, sadar akan wewenang yang disandangkan kepadanya dan memaksimalkan atau paling tidak menjaga keefektifan dan mengefisienkan sumber daya yang ada; 3 . Mampu menjaga komitmen dan adil dalam pemberian penghargaan maupun hukuman dan adil menurut pemegang keputusan terutama bagi khalayak ramai; 4. Paham alur namun tetap menghargai instansi lain yang terkait atau bekerja sama dengannya ini.

Seperti pidato pada umumnya, pidato di atas memiliki 3 bagian yaitu:

1. Pembukaan berisikan salam pembuka dan perkenalan siapa- 
2. siapa saja yang terlibat dalam proses vaksin hari tersebut

3. Isi mengenai tindak lanjut, lembaga terkait, fungsi vaksinasi

4. Penutup mengingatkan kembali pentingnya protocol kesehatan yaitu $3 \mathrm{M}$ dan salam penutup

Pidato yang singkat ini melahirkan wacana besar mengenai keterlibatan semua pihak dalam satu masalah, tidak memandang SARA dan golongan. Interaksi yang terjadi menyentuh ranah global karena diberitakan melalui jaringan media sampai ke ranah kelompok-kelompok kecil melalui aplikasi-aplikasi media sosial.

Melalui analisis wacana, isu semacam ini dapat diarahkan menjadi isu positif karena memenuhi orientasi pada tugas sesuai dengan tugas pokok dan fungsi Presiden sebagai kepala negara dan kepala pemerintahan. Interaksi melalui media mengena kepada golongan tua, muda sampai milenial untuk membuktikan bahwa vaksinasi ini hanya salah satu cara untuk memastikan setiap orang mendapatkan alternatif solusi kesehatan di masa pandemi selain kebiasaan yang diterapkan dalam protokol kesehatan yaitu cuci tangan, memakai masker dan jaga jarak.

Isu negatif juga melekat di pidato tadi. Indonesia sebagai negara berpenduduk muslim terbesar harus memastikan bahwa vaksin yang beredar telah tersertifikasi halal oleh MUI. Isu tersebut bukan kali pertama mengemuka namun telah ada sebelumnya. Direktur Utama Bio Farma, Honesti Basyir, dalam pernyataannya yang dilansir BBC kehalalan vaksin menjadi isu utama di Indonesia. Hal ini berdasarkan pengalaman vaksin rubela yang tak optimal pada 2018 lalu. Di Indonesia itu vaksin itu harus ada faktor keamanan, khasiat, mutu, dan halal.

Pidato yang singkat ini melahirkan wacana besar mengenai keterlibatan semua pihak dalam satu masalah, tidak memandang SARA dan golongan. Interaksi yang terjadi menyentuh ranah global karena diberitakan melalui jaringan media sampai ke ranah kelompok-kelompok kecil melalui aplikasi-aplikasi media sosial seperti twitter di bawah.

di suntik vaksin aja di permasalahin. Apakah kita orang2 Indonesia tidak punya masalahin lain ??? (@ivopakginting).

Langsung rame ya setelah Pak Jokowi di vaksin, Vaksin nya pasti beda dengan yang dibagiin free ke masyarakat", lebih jelasnya nonton live streaming aja deh jelas kok merk vaksin nya terpampang nyata. (@benayatiarno1)

Komersialisasi vaksin mencuat namun dibantah kemudian oleh Presiden sendiri bahwa vaksin akan dibagikan secara gratis.

Hal yang dilakukan oleh Presiden Jokowi merupakan wujud nyata dari semboyan Ki Hajar Dewantara tentang pendidikan dan kepemimpinan, yaitu: a. Ing Ngarso Sung Tulodho: di depan memberi contoh yaitu mendapatkan vaksinasi pertama; b. Ing Madya Mangun Karsa: di tengah meenemani. Dalam hal ini masyarakat terwakilkan lewat tokoh-tokoh sentral antar SARA dan golongan; c. Tut Wuri Handayani: di belakang memberikan dorongan, selaku Presiden mengupayakan informasi memakai masker, cuci tangan, jaga jarak. Hal ini sesuai dengan budaya bangsa dari jaman ke jaman. 


\section{Simpulan dan Saran}

Pidato yang singkat saat Presiden Jokowi mendapatkan vaksinasi pertama ini melahirkan wacana besar mengenai keterlibatan semua pihak dalam satu masalah, tidak memandang SARA dan golongan. Interaksi yang terjadi menyentuh ranah global karena diberitakan melalui jaringan media sampai ke ranah kelompokkelompok kecil melalui aplikasi-aplikasi media sosial. Interaksi melalui media mengena kepada golongan tua, muda sampai milenial untuk membuktikan bahwa vaksinasi ini hanya salah satu cara untuk memastikan setiap orang mendapatkan

\section{DAFTAR PUSTAKA}

Suarjaya, I Wayan; Teori Organisasi, Surabaya: Paramita

Riant, Nugroho; Kebijakan Publik, Yogyakarta: Pustaka Pelajar, 2016

https://www.bbc.com/indonesia/indonesia55584618, akses 19 Januari 2021

https://www.cnnindonesia.com/hiburan/20 210113120103-234-593065/raffiahmad-divaksin-covid-19-barengjokowi-netizen-ribut, akses 19 Januari 2021 alternatif solusi kesehatan di masa pandemi selain kebiasaan yang diterapkan dalam protokol kesehatan yaitu cuci tangan, memakai masker dan jaga jarak. Indonesia sebagai negara berpenduduk muslim terbesar harus memastikan bahwa vaksin yang beredar telah tersertifikasi halal. Kesiapan mental penting untuk dipahami dan dilaksanakan melalui mitigasi atau pencegahan secara terus menerus dan berkesinambungan. Masyarakat harus memahami dan belajar dari penanganan bencana di negara lain. Kepemimpinan berasal dari contoh akan lebih efisien dan efektif

https://news.detik.com/berita/d-

5333343/dear-raffi-ahmad-inipidato-presiden-ingatkan-taatprokes-meski-sudah-divaksin/2, akses tanggal 19 Januari 2021 